\title{
Lisianthus Leaf Necrosis: A New Disease of Lisianthus Caused by Iris yellow spot virus
}

A. Kritzman, H. Beckelman, S. Alexandrov, J. Cohen, and M. Lampel, Department of Virology, Agricultural Research Organization, The Volcani Center, Bet Dagan 50250, Israel; M. Zeidan, The Plant Protection and Inspection Services, Ministry of Agriculture, Bet Dagan 50250, Israel; and B. Raccah and A. Gera, Department of Virology, Agricultural Research Organization, The Volcani Center, Bet Dagan 50250, Israel

\begin{abstract}
Kritzman, A., Beckelman, H., Alexandrov, S., Cohen, J., Lampel, M., Zeidan, M., Raccah, B., and Gera, A. 2000. Lisianthus leaf necrosis: A new disease of lisianthus caused by Iris yellow spot virus. Plant Dis. 84:1185-1189.

Unusual viral symptoms were seen on lisianthus (Eustoma russellianum) grown in the Besor area in Israel. Symptoms included necrotic spots and rings on leaves and systemic necrosis. Preliminary analyses suggested that the disease was caused by a tospovirus. Virus particles typical of a tospovirus were observed with electron microscopy in samples taken only from symptomatic leaves. Double-antibody sandwich enzyme-linked immunosorbent assay tests of leaf sap, extracted from lisianthus and mechanically inoculated indicator plants, gave a strong positive reaction to Iris yellow spot virus (IYSV). Polyclonal antibodies prepared against IYSV enabled specific detection of the virus in crude sap from infected plants. Western blot analysis showed that IYSV was serologically distinct from Tomato spotted wilt virus (TSWV). Primers specific to the nucleocapsid gene of IYSV were used in a reverse transcription-polymerase chain reaction assay (RT-PCR) to verify the presence of IYSV. RT-PCR gave an expected PCR product of approximately $850 \mathrm{bp}$. The sequence of the cloned nucleocapsid gene confirmed the identity of IYSV, thus confirming IYSV infection of lisianthus. This is the first report of IYSV infection in dicotyledons.
\end{abstract}

Additional keyword: IYSV, thrips, tospovirus

Lisianthus (Eustoma russellianum (Don) Griseb), a member of the family Gentianaceae, is endemic to the prairies of the south midwest United States. The plant was introduced into Japan some decades ago and is becoming a popular cut flower in the world market. Lisianthus was introduced into Israel in the 1980 s for cut flower production. The crop is highly susceptible to virus diseases: about 10 viruses have been reported in this crop $(4,7,14)$. Both Tomato spotted wilt virus and Impatiens necrotic spot virus have been detected in lisianthus (14).

We reported the occurrence of Iris yellow spot virus (IYSV) in onion (Allium cepa L.) in Israel (8), where the incidence of the disease often reached 50 to $60 \%$, resulting in heavy losses of onion-bulb production. The virus has also been detected in Iris hollandica Tub. grown in the Netherlands (5) and in onion grown in Brazil and the United States $(11,16)$.

During 1999, field-infected lisianthus plants showing necrotic spots and rings on

Corresponding author: A. Gera

E-mail: abedg@netvision.net.il

Accepted for publication 14 July 2000.

Publication no. D-2000-0823-01R

(C) 2000 The American Phytopathological Society leaves and stems, and top necrosis, were observed. The goal of the present study was to characterize the causal agent of lisianthus leaf necrosis.

\section{MATERIALS AND METHODS}

Virus and plants. IYSV was isolated from lisianthus (E. russellianum) leaves and maintained in Nicotiana benthamiana Domin. by mechanical inoculation. To determine host range, leaf tissue of IYSVinfected lisianthus was ground in $0.01 \mathrm{M}$ sodium phosphate buffer, $\mathrm{pH} 7.0$, containing $0.1 \%$ sodium sulfite, and mechanically inoculated onto $N$. benthamiana, N. glutinosa L., N. rustica L., N. clevelandii A. Gray, Gomphrena globosa L., Chenopodium quinoa Wild., C. amaranticolor Coste and Reyn, Emilia sonchifolia (L.) DC., Cucurbita sativus L., Datura stramonium L., Lycopersicum esculentum Mill., and Petunia hybrida. Plants were kept under greenhouse conditions and observed for symptom expression.

Thrips transmission. A local population of healthy Thrips tabaci grown in our laboratory was used for transmission experiments. First instar larvae of 2- to 14-h post hatching were reared on naturally infected lisianthus and allowed to move freely to healthy lisianthus seedling grown from seeds and placed in the same cage. Plants were assayed for symptom expression for 4 weeks. Virus presence was as- certained by enzyme-linked immunosorbent assay (ELISA).

In further experiments, populations of $T$. tabaci adults were collected from onion fields naturally infected with IYSV. Lisianthus seedling grown from seeds and tested for IYSV by ELISA were used for thrips transmission experiments. Five thrips were placed on each healthy seedling for 2 days of inoculation access feeding. Plants were kept under greenhouse conditions and assayed for symptom expression. Virus presence was ascertained by ELISA.

Electron microscopy. Crude plant extracts in $0.1 \mathrm{M}$ phosphate buffer, or virus preparations, were negatively stained with $1 \%$ uranyl acetate and examined for virus by electron microscopy. Ultrathin sections $(2 \times 1 \mathrm{~mm})$ were excised from symptomatic young leaves of E. russellianum and $N$. benthamiana and fixed in $2.5 \%$ glutaraldehyde buffered with $75 \mathrm{mM}$ potassium phosphate, $\mathrm{pH} 7.0$, for $2 \mathrm{~h}$. Samples were then rinsed in the same buffer and postfixed in $1 \% \mathrm{OsO}_{4}$ for $3 \mathrm{~h}$. After a buffer rinse, the samples were dehydrated in a graded acetone series, embedded in an Epon-Araldite resin mixture, and polymerized as described by Orion and Franck (15). Sectioned material was stained with uranyl acetate followed by lead nitrate and examined for virus by electron microscopy.

Purification and serology of nucleocapsids. Nucleocapsids (NC) were purified from systemically infected $N$. benthamiana 10 days after inoculation according to the method of de Avila et al. (6).

Purified NC proteins (about $0.1 \mathrm{mg} / \mathrm{ml}$ ) were emulsified with an equal volume of Freund's incomplete adjuvant and injected intramuscularly into both hip muscles of a 6-week-old female rabbit. Injections were repeated weekly for 4 weeks and serum was collected 2 weeks after the last injection. The titer of antiserum was tested by Western blotting and ELISA (3).

SDS-polyacrylamide gel electrophoresis (SDS-PAGE) and western blots. The molecular weight $\left(M_{\mathrm{r}}\right)$ of IYSV NC was determined by SDS-PAGE; $12 \%$ polyacrylamide gels $(75 \times 5 \mathrm{~mm})$ were prepared as described previously $(9,12)$. The protein bands were either stained with $0.1 \%$ Coomassie brilliant blue or electroblotted to nitrocellulose (19) and probed with the polyclonal antiserum. Antibody binding was detected with goat anti-rabbit 
IgG conjugated to alkaline phosphatase (BioMakor, Rehovot, Israel).

RNA isolation, cloning of $\mathbf{N}$ gene. Viral RNA was extracted from systemically infected $N$. benthamiana according to the method of Verwoerd et al. (20). Firststrand cDNA was primed on total plant RNA using a specific primer IY1 (5'-

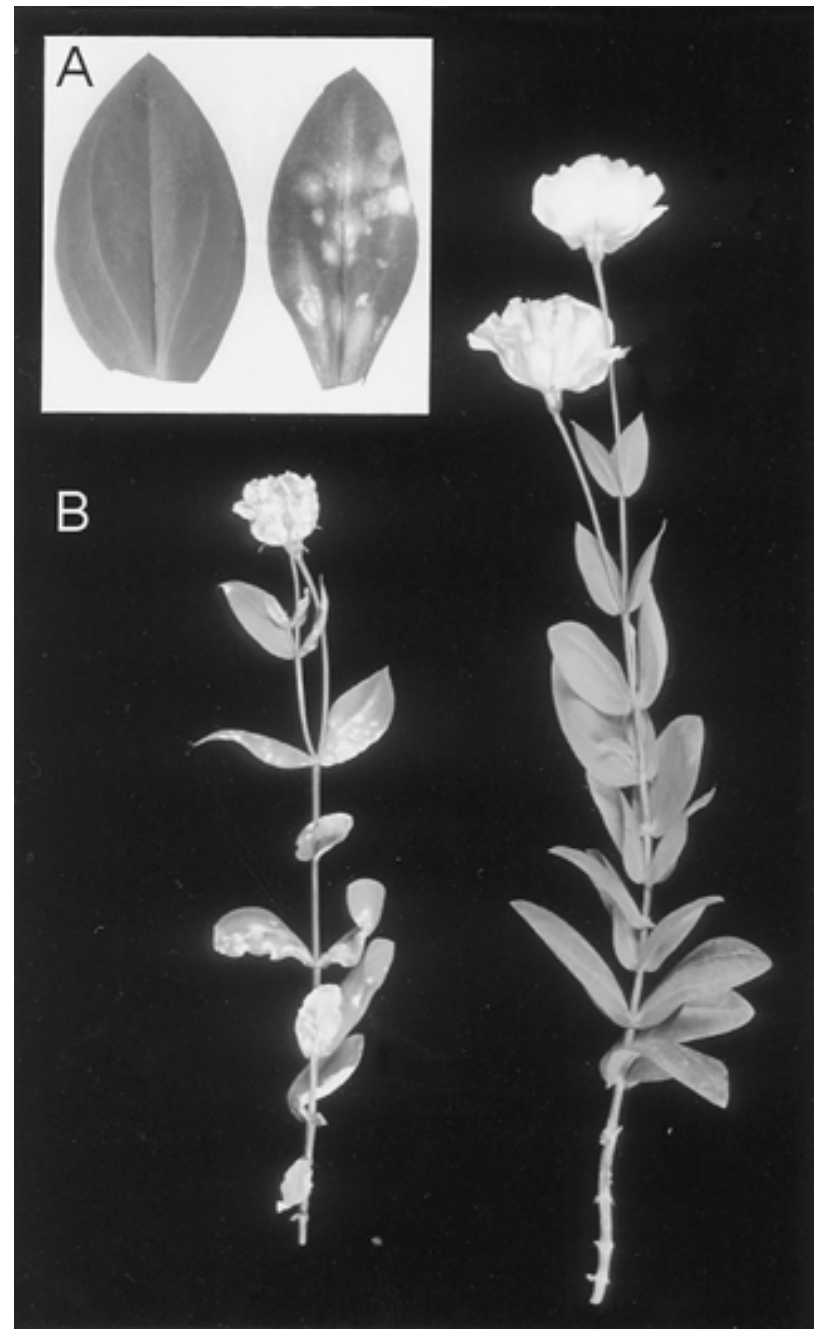

Fig. 1. Symptoms of Iris yellow spot virus (IYSV) on lisianthus (A) healthy (left) and naturally infected (right) leaves and (B) mechanically inoculated plants.
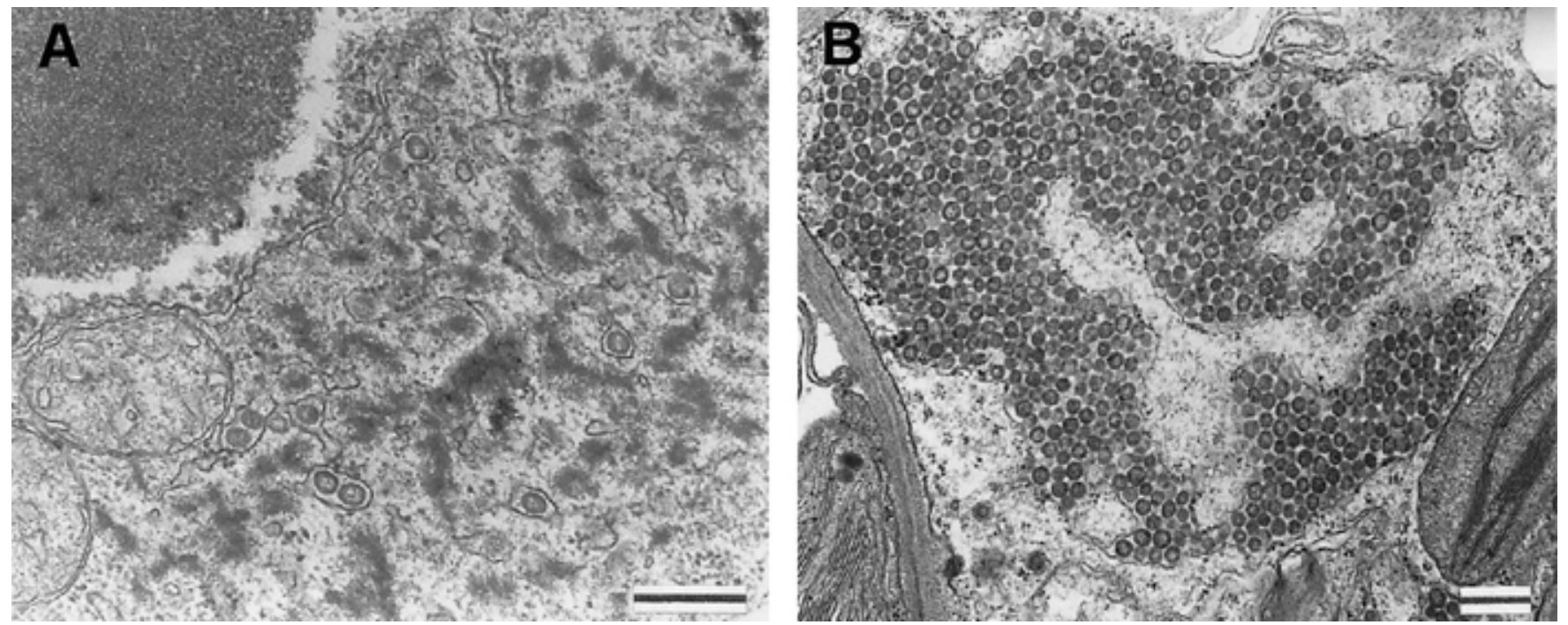

Fig. 2. Electron micrograph of enveloped Iris yellow spot virus (IYSV) virions and double-membraned structures in thin sections of (A) naturally infected lisianthus and $(\mathbf{B})$ mechanically inoculated Nicotiana benthamiana $($ Bar $=500 \mathrm{~nm})$. 
distorted, compared with healthy ones. Virus-free lisianthus plants were mechanically inoculated with plant sap from naturally infected lisianthus or purified virus obtained from infected $N$. benthamiana. Symptoms that developed on mechanically infected lisianthus were identical to those observed on naturally infected plants. Similar results were obtained when lisianthus plants were mechanically inoculated with IYSV isolated from onion. To confirm symptom development by thrips transmission, a colony of $T$. tabaci grown in our laboratory was introduced onto naturally infected lisianthus plants, and adults developing on these plants were exposed to virus-free lisianthus seedlings. Thrips transmitted the virus to five out of eight plants, as confirmed by ELISA. In further experiments, groups of adult $T$. tabaci that had been collected in the field from onions infested with IYSV were used to inoculate virus-free lisianthus seedlings. IYSV transmission was confirmed in seven out of ten plants that showed symptom and ascertained by ELISA. This experiment is the first confirmation of Koch's postulates for IYSV.

Host range. Plant species that had previously been utilized to determine the host range of various tospoviruses $(2,13)$ were mechanically inoculated with IYSV. Whereas most plant species reacted locally with chlorotic or necrotic lesions, the Israeli isolate of IYSV systemically infected only $N$. benthamiana and G. globosa. On inoculated $N$. benthamiana, chlorotic spots on inoculated leaves and systemic necrosis developed 5 and 10 days post inoculation (DPI), respectively. On inoculated leaves of $C$. quinoa and $G$. globosa, necrotic local lesions developed within 4 to 5 DPI. Occasionally, necrotic local lesions developed on D. stramonium and P. hybrida. The virus did not infect Cucumis sativus, Datura stramonium, Lycopersicon esculentum, $N$. tabacum, $N$. glutinosa, or N. rustica.

Electron microscopy. Electron microscopy (EM) analysis of infected plant tissues demonstrated the presence of spherical enveloped particles 80 to $120 \mathrm{~nm}$ in diameter (data not shown). Ultrathin sections of naturally infected lisianthus showed tospovirus-like particles and membranous structures that were not observed in noninfected controls (Fig. 2A). In cells of mechanically inoculated $N$. benthamiana, numerous spherical particles were always observed within membrane-bound vesicles (Fig. 2B); these particles were similar in structure and size to those found in dip preparations.

ELISA. Presence of IYSV in plants was determined by double-antibody sandwich (DAS)-ELISA using the antiserum against the IYSV NC. ELISA values $\left(\mathrm{OD}_{405}\right)$ of samples from field-infected lisianthus and mechanically infected $N$. benthamiana diluted 1:100 were 1.45 and 1.60 , respectively.
SDS-PAGE and immunoblotting. $\mathrm{Pu}-$ rified IYSV NC material, when denatured with SDS and analyzed by PAGE, revealed one major polypeptide band (Fig. 3A, lane 1). The $M_{\mathrm{r}}$ of the $\mathrm{N}$ protein was estimated to be 32,500 daltons.

Immunoblots with the antiserum against the IYSV NC gave a clear and strong reaction with the polypeptide corresponding to the $\mathrm{N}$ protein (Fig. 3B). No signal was obtained when antiserum against TSWV nucleocapsid was applied (Fig. 3C), suggesting that the virus was serologically distinct from TSWV.

Cloning the IYSV nucleocapsid gene. The $\mathrm{N}$ gene of IYSV from lisianthus was amplified by RT-PCR. A fragment of about 850 nucleotides was cloned with the pGEM T/A-cloning kit. The nucleotide sequence of the clone was established and deposited in the GenBank database under the accession number AF271219. The $\mathrm{N}$ gene fragment contained 825 nucleotides encoding for a protein of 273 amino acids. The predicted molecular weight of this protein would then be $32 \mathrm{kDa}$, which fits well with the observed size $(32.5 \mathrm{kDa})$. A multiple alignment of the deduced $\mathrm{N}$ protein amino acid sequence of IYSV from lisianthus showed 96 and $91 \%$ identity with those of the Dutch and Brazilian strains, respectively (Fig. 4). The results suggest that the Israeli IYSV shares high identity with both the Dutch and Brazilian strains, and that all are clearly distinct from other tospoviruses.

\section{DISCUSSION}

In this article, we provide evidence for a new disease in lisianthus caused by IYSV. This newly emerged virus has been reported from the New and Old Worlds. IYSV was initially identified in onion $(A$. серa) and Hippeastrum in Israel (8) and in iris (I. hollandica) in the Netherlands (5) and recently was detected in onion in Brazil (16). All of these crops are monocotyledons and members of the family Liliaceae. The detection of the virus in lisianthus is the first report of a natural infection of IYSV in dicotyledons. In order to ascertain authenticity of the virus from lisianthus, Koch's postulates were confirmed both by mechanical inoculation of purified virions and thrips transmission. Moreover, this is the first report demonstrating Koch's postulates for IYSV.

In ultrathin sections of cells from infected lisianthus and $N$. benthamiana, spherical particles were observed within membrane-bound vesicles only in symptomatic tissues of infected plants. The membranous structures observed in infected lisianthus may be virus-related or may result from cytopathology.

Unlike the type member of the Tospovirus genus, IYSV apparently has a relatively narrow host range. However, a slightly different host range has been reported for the Israeli IYSV strain compared to the strains from Brazil and the Netherlands. The Israeli IYSV strain systemically infected the experimental hosts

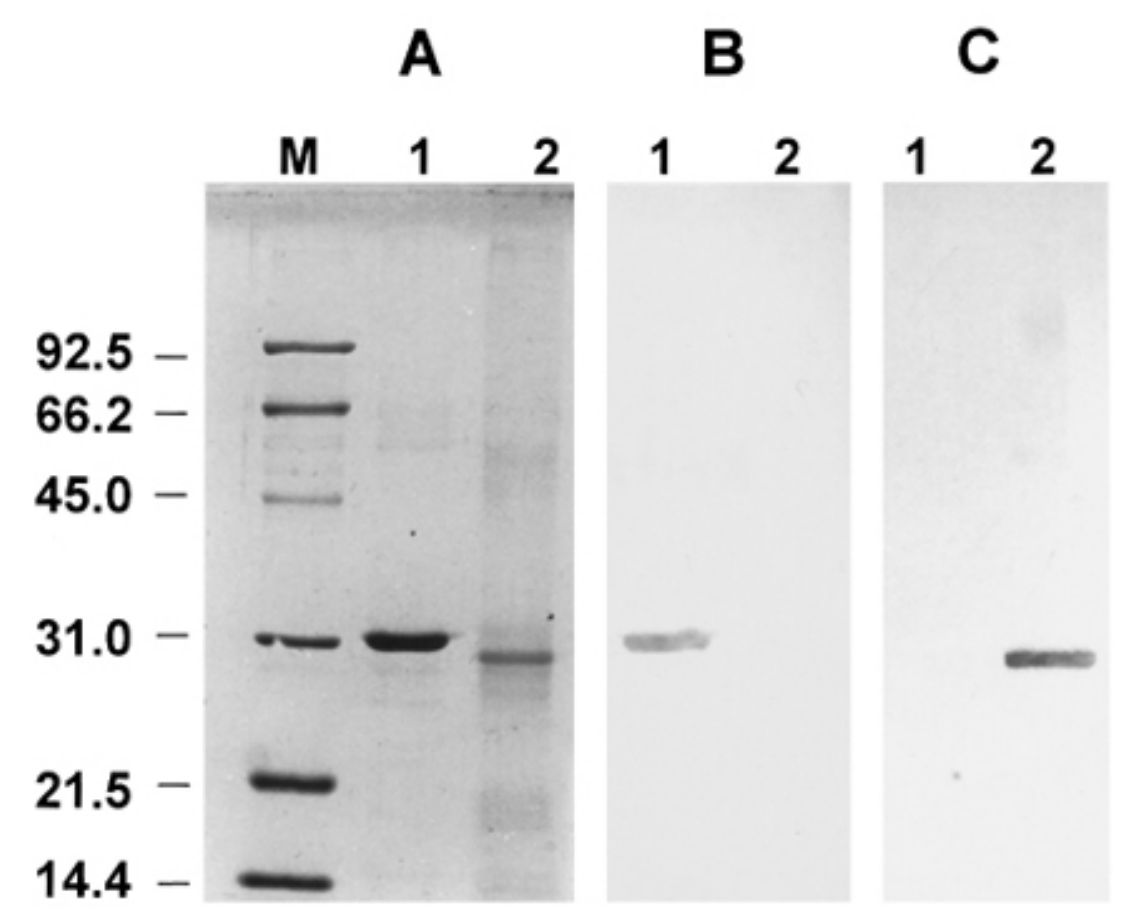

Fig. 3. Sodium dodecyl sulfate-polyacrylamide gel electrophoresis and immunoblots of the nucleocapsid (N) proteins of Iris yellow spot virus (IYSV) from lisianthus and Tomato spotted wilt virus (TSWV) from pepper. Panel A: stained with Coomassie brilliant blue. Lane M, molecular weight markers: phosphorylase b $(92.5 \mathrm{kDa})$, bovine serum albumin $(66.2 \mathrm{kDa})$, aldolase $(45 \mathrm{kDa})$, carbonic anhydrase $(31 \mathrm{kDa})$, trypsin inhibitor $(21.5 \mathrm{kDa})$, and lysozyme $(14.4 \mathrm{kDa})$; lanes 1 and 2 , N-proteins of IYSV and TSWV, respectively. Panels B and C: gels were blotted on membranes and probed with IYSV and TSWV polyclonal antibodies (diluted 1:2,000), respectively. 
$N$. benthamiana and G. globosa, and induced necrotic local lesions in $C$. quinoa and occasionally $D$. stramonium and $P$. hybrida but not $N$. rustica. The Brazilian strain of IYSV infected $N$. rustica but not P. hybrida (16), while the Dutch strain systemically infected $D$. stramonium but not $N$. rustica (5). These differences in the host range are also reflected in the nucleotide sequence. Thus, nucleotide sequences of the $\mathrm{N}$ gene of IYSV showed a close relationship with both the Dutch and the Brazilian strains. Identity was more than $90 \%$, which has been set as the threshold value below which isolates are regarded as distinct tospovirus species (10). IYSV from lisianthus should be considered a strain of the virus and it has been designated IYSV-IL. The high significant homology with the Dutch strain (96\%) in the amino acid sequence can be attributed to a recent introduction of IYSV from one country to another. Since the first incidence of IYSV in Israel was in Hippeastrum imported from the Netherlands (8), the virus probably was introduced into Israel from the Netherlands via ornamental propagation material. However, the divergence of the amino acid sequences from those of the Brazilian strain $(9 \%)$ may reflect adaptation to different hosts and environmental conditions. In view of the

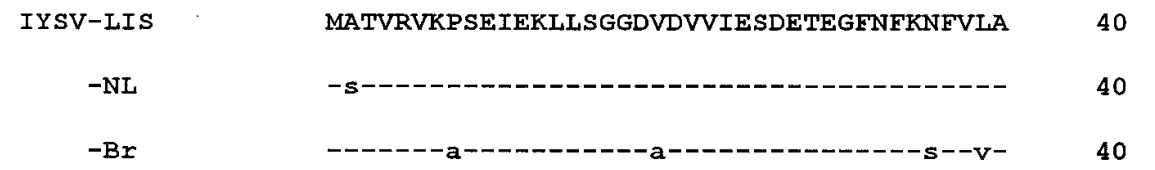

IYSV-LI

$$
\text { -NL }
$$$$
-B r
$$

NEGVQMTFNNGYTI LRNRAGIYKTIKSGKFTFQGKTIVIP

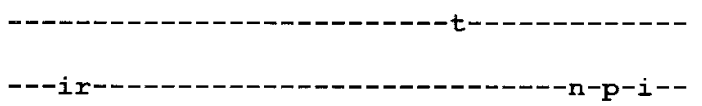

IYSV-LIS

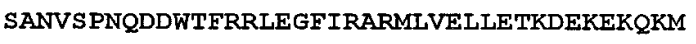

$-\mathrm{NL}$

$-\mathrm{Br}$

IYSV-LIS

YEKICGLPLVSAYGLKLSSKFDATTARIMLALGGPLTLLA

$-\mathrm{NL}$

$-\mathrm{Br}$

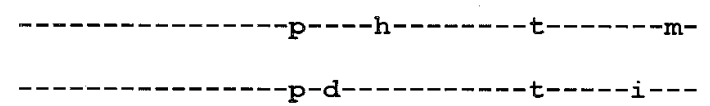

IYSV-LIS

SLDI FAAAVLPLAYFQNVKKEALGI SRFSTYEQLCKVARV

$-\mathrm{NL}$

$-\mathrm{Br}$

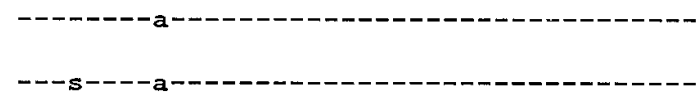

200

200

IYSV-LIS

MAAKEYKETEKYKKIFDETVKILTDCTPGTSGAASLIKFN

$-\mathrm{NL}$

$-B r$

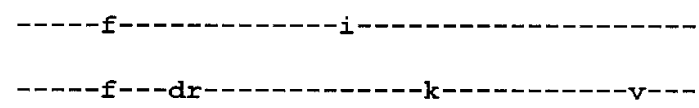

240

240

240

IYSV-LIS

EQYKILEGAFGKIVEDIGESSKPKNPSKKDRYN

273

$-\mathrm{NI}$
$-\mathrm{Br}$

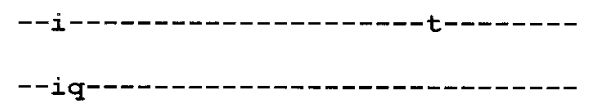

273

273

Fig. 4. Multiple sequence alignment of nucleocapsid proteins of Iris yellow spot virus from lisianthus (IYSV-IL), from iris in the Netherlands (IYSV-NL, AF001387) and from onion in Brazil (IYSV-Br, AF067070). wide distribution of IYSV in onion fields in Israel and the abundance of the thrips vector on onions, it could be that the virus has been introduced from onion to lisianthus. This assumption is supported by the fact that the strain found in Israel in lisianthus is identical to that reported in onion: both have identical sequences of the $\mathrm{N}$ gene, and cross-reacted with polyclonal antibodies produced against the nucleocapsid (data not shown).

The $M_{\mathrm{r}}$ of $32.5 \mathrm{kDa}$ observed in SDSPAGE for IYSV nucleocapsid was in good agreement with those published for the Dutch and the Brazilian strains $(5,16)$, but not with the $M_{\mathrm{r}}$ of $28 \mathrm{kDa}$ calculated for TSWV and other tospoviruses.

Up till now, the outbreak of IYSV in lisianthus is sporadic and limited. This is in contrast to epidemics of this virus in onion, where the disease has an important economic impact. The epidemics in onion is attributed to the large population of $T$. tabacci. It seems that the virus is newly adapted to lisianthus. The detection of IYSV in lisianthus may have an impact on the lisianthus industry in Israel.

\section{ACKNOWLEDGMENTS}

Contribution from the Agricultural Research Organization, The Volcani Center, Bet Dagan, Israel. No. 521/00 series. This work was supported in part by the United States-Israel Binational Agricultural Research and Development Fund (BARD).

\section{LITERATURE CITED}

1. Altschul, S. F., Gish, W., Miller, W., Myers, E. W., and Lipman, D. J. 1990. Basic local alignment search tool. J. Mol. Biol. 215:403410.

2. Antignus, Y., Lapidot, M., Ganaim, N., Cohen, J., Lachman, O., Pearlsman, A., Raccah, B., and Gera, A. 1997. Biological and molecular characterization of tomato spotted wilt virus in Israel. Phytoparasitica 25:319-330.

3. Clark, M. F., and Adams, A. N. 1977. Characteristics of the microplate method of enzyme linked immunosorbent assay for the detection of plant viruses. J. Gen. Virol. 34:475-483.

4. Cohen, J., Gera, A., Ecker, R., Ben-Joseph, R., Perlsman, M., Gokkes, M., and Antignus, Y. 1995. Lisianthus leaf curl a new disease of lisianthus (Eustoma grandiflorum) caused by tomato yellow leaf curl virus (TYLCV). Plant Dis. 79:416-420.

5. Cortês, I., Livieratos, J., Derks, A., Peters, D., and Kormelink, R. 1998. Molecular and serological characterization of iris yellow spot virus, a new and distinct tospovirus species. Phytopathology 88:1276-1282.

6. De Ávila, A. C., de Haan, P., Kitajima, E., Kormelink, R., Resende, R. de O., Goldbach, R., and Peters, D. 1992. Characterization of a distinct isolate of tomato spotted wilt virus (TSWV) from Impatiens sp. in the Netherlands. J. Phytopathol. 134:133-151.

7. Gera, A., and Cohen, J. 1990. The natural occurrence of bean yellow cucumber and tobacco mosaic viruses in lisianthus in Israel. Plant Pathol. 39:561-564.

8. Gera, A., Cohen, J., Salomon, R., and Raccah, B. 1998. Iris yellow spot tospovirus detected in onion (Allium cepa) in Israel. Plant Dis. $82: 127$.

9. Gera, A., Loebenstein, G., Salomon, R., and Franck, A. 1990. An inhibitor of virus repli- 
cation (IVR) from protoplasts of a hypersensitive tobacco cultivar infected with tobacco mosaic virus is associated with a $23 \mathrm{~K}$ protein species. Phytopathology 80:78-81.

10. Goldbach, R., and Kuo, G. 1996. Introduction. In: International Symposium on Tospoviruses and Thrips of Floral and Vegetable Crops. Acta Hortic. 431:21-26.

11. Hall, J. M., Mohan, K., Knott, E. A., and Moyer, J. W. 1993. Tospoviruses associated with scape blight of onion (Allium cepa) seed crops in Idaho. Plant Dis. 77:952.

12. Laemmli, U. K. 1970. Cleavage of structural proteins during the assembly of the head of bacteriophage T4. Nature (London) 227:680685.

13. Le, T. S. 1970. Tomato spotted wilt virus.
C.M.I./A.A.B. Description of plant viruses no. 39,1970 .

14. Lisa, V., and Gera, A. 1995. Lisianthus. Pages 443-448 in: Virus and Virus-Like Diseases of Bulb and Flower Crops. G. Loebenstein, R. Lawson, and A. Brunt, eds. Wiley, Chichester, U.K.

15. Orion, D., and Frank, A. 1990. An electron microscopy study of cell wall lysis by Meloidgyne javanica gelatinous matrix. Rev. Nematol. 13:105-107.

16. Pozzer, L., Bezerra, I. C., Kormelink, R., Prins, M., Peters, D., Resende, R. de O., and de Avilla, A. C. 1999. Characterization of a tospovirus isolate of iris yellow spot virus associated with a disease in onion fields in Brazil. Plant Dis. 83:345-350.
17. Sambrook, J., Fritsch, E. F., and Maniatis, T 1989. Molecular Cloning. A Laboratory Manual. 2nd ed. Cold Spring Harbor Laboratory, Cold Spring Harbor, N.Y.

18. Sanger, F., Nicklen, S., and Coulsons, A. R 1977. DNA sequencing with chain-terminating inhibitors. Proc. Natl. Acad. Sci. USA 74:5463-5467.

19. Towbin, H., Staehelin, T, and Gordon, J. 1979. Electrophoretic transfer of protein from polyacrylamide gels to nitrocellulose sheets: procedure and some applications. Proc. Natl. Acad. Sci. U.S.A. 76:4350-4354.

20. Verwoerd, T. C., Dekker, B. M. M., and Hoekema, A. 1989. A small-scale procedure for the rapid isolation of plant RNAs. Nucleic Acids Res. 17:1763-1771. 